\title{
Using long-term data to predict fish abundance: the case of Prochilodus lineatus (Characiformes, Prochilodontidae) in the intensely regulated upper Paraná River
}

\author{
Pitágoras A. Piana ${ }^{1}$, Bárbara F. Cardoso ${ }^{2}$, Joilson Dias ${ }^{3}$, Luiz C. Gomes ${ }^{4}$, \\ Angelo A. Agostinho ${ }^{4}$ and Leandro E. Miranda ${ }^{5}$
}

Populations show spatial-temporal fluctuations in abundance, partly due to random processes and partly due to self-regulatory processes. We evaluated the effects of various external factors on the population numerical abundance of curimba Prochilodus lineatus in the upper Paraná River floodplain, Brazil, over a 19-year period. Panel data analysis was applied to examine the structure of temporal and spatial abundance while controlling auto-regressive processes and spatial non-homogeneity variances that often obscure relationships. As sources of population variation, we considered predation, competition, selected abiotic variables, construction of a dam upstream of the study area, water level and flood intensity during the spawning period. We found that biological interactions (predation and competition) were not significantly related to variations in curimba abundance; specific conductance was a space indicator of abundance, apparently linked to the biology of the species; intensity of floods determined inter-annual variation in abundances; Porto Primavera Dam negatively impacted the abundances at sites in the floodplain directly affected by discharges from the dam. Panel data analysis was a powerful tool that identified the need for intense flooding to maintain high abundances of curimba in the upper Paraná River. We believe our results apply to other species with similar life strategy.

Keywords: Abiotic conditions, Biological interactions, Dam, Floodplain, Flood pulse.

As populações apresentam flutuações espaço-temporais em abundância devido a processos aleatórios e auto-regulatórios. Nesse trabalho avaliamos efeitos de vários fatores sobre a abundância da curimba, Prochilodus lineatus, em cinco ambientes da planície de inundação do alto rio Paraná, Brasil, durante 19 anos. A análise de dados em painel foi utilizada por examinar variações espaço-temporais na abundância considerando processos auto-regressivos e variâncias espacialmente heterogêneas, que por vezes dificultam a identificação das relações. Como fontes de variação na abundância da curimba foram consideradas: predação, competição, variáveis abióticas selecionadas, construção da barragem de Porto Primavera, nível da água do rio Paraná e intensidade de cheia no período reprodutivo. Foi identificado que predação e competição não foram significativamente associadas às abundâncias da curimba; condutividade específica foi indicadora espacial da abundância; intensidade das cheias foi determinante de variações interanuais na abundância; barragem de Porto Primavera influenciou, negativamente, a abundância em corpos d'água diretamente afetados. A análise de dados em painel mostrou ser uma poderosa ferramenta preditiva, que possibilitou identificar a necessidade de cheias intensas para manutenção de elevadas abundâncias de curimba no alto rio Paraná. Acreditamos que o mesmo seja válido espécies de peixes que apresentam estratégia de vida similar.

Palavras-chave: Barragem, Condições abióticas, Interações biológicas, Planície de inundação, Pulso de inundação.

${ }^{1}$ Programa de Pós-Graduação em Recursos Pesqueiros e Engenharia de Pesca, Universidade Estadual do Oeste do Paraná, Rua da Faculdade 645, 85903-000 Toledo, PR, Brazil. pitapiana@yahoo.com.br (corresponding author)

${ }^{2}$ Programa de Pós-Graduação em Desenvolvimento Regional e Agronegócio, Universidade Estadual do Oeste do Paraná, Rua da Faculdade 645, 85903-000 Toledo, PR, Brazil. barbarafcardoso@gmail.com

${ }_{3}^{3}$ Departamento de Economia, Universidade Estadual de Maringá. Av. Colombo 5790, 87020-900 Maringá, PR, Brazil. jdias@uem.br ${ }^{4}$ Programa de Pós-Graduação em Ecologia de Ambientes Aquáticos Continentais, Universidade Estadual de Maringá, Av. Colombo 5790, 87020-900 Maringá, PR, Brazil. (LCG) gomes.luizcarlos@gmail.com, (AAA) agostinhoaa@gmail.com

${ }^{5}$ U. S. Geological Survey, Mississippi Cooperative Fish and Wildlife Research Unit, P.O. Box 9691, Mississippi State, MS 39762, United States.smiranda@usgs.gov 


\section{Introduction}

Populations show abundance fluctuations in time and space, partly due to random processes and partly due to self-regulatory processes. Diverse factors can act as regulators of populations, such as climate, physical and chemical conditions, barriers of dispersion, biological interactions and anthropogenic actions (Jackson et al., 2001; Hixon et al., 2002). Understanding how these factors intervene in population control is fundamental to the development of conservation strategies, and a central theme in ecology (Turchin, 2001).

Currently, most fluvial systems require interventions to maintain biological diversity. Over time, fluvial systems have been intensely modified, with profound consequences on native communities (Ward, Stanford, 1995). In the Paraná River, the gradual construction of hydroelectric dams has transformed a lotic environment into a cascade of reservoirs, with negative implications to the aquatic fauna, particularly migratory fishes. Changes in the hydrological regime and water quality downstream, imposed by dams, have been identified as the precursors of these impacts (Agostinho et al., 2004a, 2004b).

It is widely known that the hydrological regime is the main factor structuring riverine assemblages, a notion that has been articulated in the flood pulse concept (Junk et al., 1989; Neiff, 1990). Floods promote homogenization of physical, chemical and biotic components among habitats of river-floodplain systems, in both temperate and tropical realms. When the floods recede, biotic communities track distinct trajectories directed by forces that act at local scales, such as the presence of efficient predators, leading to spatial heterogeneity (Thomaz et al., 2007). Timing and duration are random variables that moderate the effects of floods (Bunn, Arthington, 2002; Agostinho et al., 2004a).

Migratory fish species in the Paraná River are highly dependent on floods to stimulate migrations that fulfill life cycles. Thus, the absence of floods can seriously affect recruitment (Agostinho et al., 2004a). At Itaipu Reservoir, where a large proportion of the curimba Prochilodus lineatus (Valenciennes, 1837) population is fished commercially, fish undergo upriver migrations during floods to spawn in tributaries; after hatching larvae drift downstream reaching floodplain lakes and migrants return to the reservoir when water level recedes (Agostinho et al., 1993). Juveniles remain in the floodplain, where they may find favorable conditions for development, until they reach adulthood and move into the Paraná River (Gomes, Agostinho, 1997).

Several factors regulate fish populations during juvenile stages in the upper Paraná River floodplain, such as the effect of the abundance of predator fish on the density of prey fish (Agostinho et al., 2001; Okada et al., 2003; Piana et al., 2006a; Petry et al., 2010). Competition between co-generic species with similar feeding and reproductive strategies has also been identified as source of population regulation (Agostinho, Júlio Júnior, 2002; Alexandre et al., 2004). Other factors that reportedly exert strong influence on fish population and community characteristics include the surface area and water clarity (indexed by Secchi depth) of floodplain lakes (Okada et al., 2003; Piana et al., 2006b).

As emphasized by Hixon et al. (2002), species show populationfluctuations as an adaptive response to modifications in physical, chemical and biological habitat characteristics. Such fluctuations have traditionally been analyzed with multiple regression, analyses of time series, dynamic models, analyses of canonic correlation (direct gradient analysis), and analyses of dimensional reduction followed by correlations (indirect gradient analysis) (see Legendre, Legendre, 1998). However, those methods are unable to simultaneously control processes related to spatial-time structure. Panel data analyses integrate space and time explicitly and when auto-regressive processes and/or spatial heteroscedasticity in the residuals are identified, they can be controlled to produce estimates that are statistically robust (Greene, 2003). Special care should be taken on hypotheses test associated with panel data, because all problems associated with time series and crosssection regressions (multiple regression) can be present. Panel data analysis is a powerful predictive tool, which combines multiple regression and time series analyses, and it is widely used in econometric studies (Greene, 2003). However, we found no ecology-oriented publications applying panel data analyses to predict variations in abundance.

As the upper Paraná River is actually regulated by a series of dams in cascades, water level fluctuations can be partially manipulated to avoid negative impacts on the fish assembly present on its remnant floodplain. We applied panel data analysis to explore the effect of flood intensity in the reproduction period over the abundance of $P$. lineatus taking in consideration other variables (external factors) that potentially regulate abundance of this species, to avoid bias in estimation of parameters related to the flood. Female curimba in the study area reach maturity size $\left(\mathrm{L}_{100}\right)$ at $24 \mathrm{~cm}$ and have a maximum standard length of $54 \mathrm{~cm}$ (Suzuki et al., 2004). Adults show maximum gonodasomatic index of nearly $20 \%$ and they can migrate hundreds of kilometers along the Paraná River in search for suitable reproductive habitats, in the Paraná River main channel or in its tributaries, where one individual can potentially spawn nearly 1.600 .000 eggs in a breeding season, that occurs from October to March (Agostinho et al., 1993; Vazzoler, 1996). Development of juveniles relies to a large extent on habitats available in the upper Paraná River floodplain (Gomes, Agostinho, 1997), where there is no commercial fishing because the floodplain is protected within the "Parque Nacional das Ilhas e Várzeas do rio Ivinhema". Modifications to the floodplain hydrograph by dams upstream have contributed to decline of curimba populations as well as several other species with similar reproductive strategies (Okada et al., 2005). Our goal was to determine the most important variables affecting population abundance of curimba, and to apply the predictive power of the panel data analysis model to advocate for management actions directed at restoring stocks of curimba and related species in the Paraná River. 


\section{Material and Methods}

Study area. Our study was conducted in the protected remnant floodplain of the upper Paraná River $\left(22^{\circ} 00^{\prime}\right.$ $23^{\circ} 00^{\prime} \mathrm{S}$; $53^{\circ} 00^{\prime}-53^{\circ} 45^{\prime} \mathrm{W}$; Fig. 1 ), downstream of the hydroelectric power plant Engenheiro Sergio Motta that, in 1998, formed Porto Primavera Reservoir. Downstream from the study floodplain is the Itaipu Reservoir formed in 1982. The remnant floodplain extends over a $230-\mathrm{km}$ stretch of the Paraná River and plays a fundamental role in the maintenance of fish populations and regional aquatic biological diversity (Agostinho et al., 2001).

Situated in the west margin of the Parana River, the floodplain includes a high diversity of habitats, with ample flooded areas, islands, lakes and canals. All these habitats are affected by the variations in water level of the Paraná River, including two major tributaries, namely the Ivinhema and Baia rivers. The Ivinhema River, unlike the Paraná and Baia rivers, has no dams. However, as the Ivinhema River flows into the Paraná River (Fig. 1), passing through the Paraná River floodplain, it is influenced by water level variations of the Paraná River. In addition, the Baia and Ivinhema rivers can partially flood the floodplain following strong local rain events, but large changes in water level in the floodplain are still controlled by the Paraná River, despite the intense change in its hydrograph forced by upstream dams (Agostinho et al., 2004b).

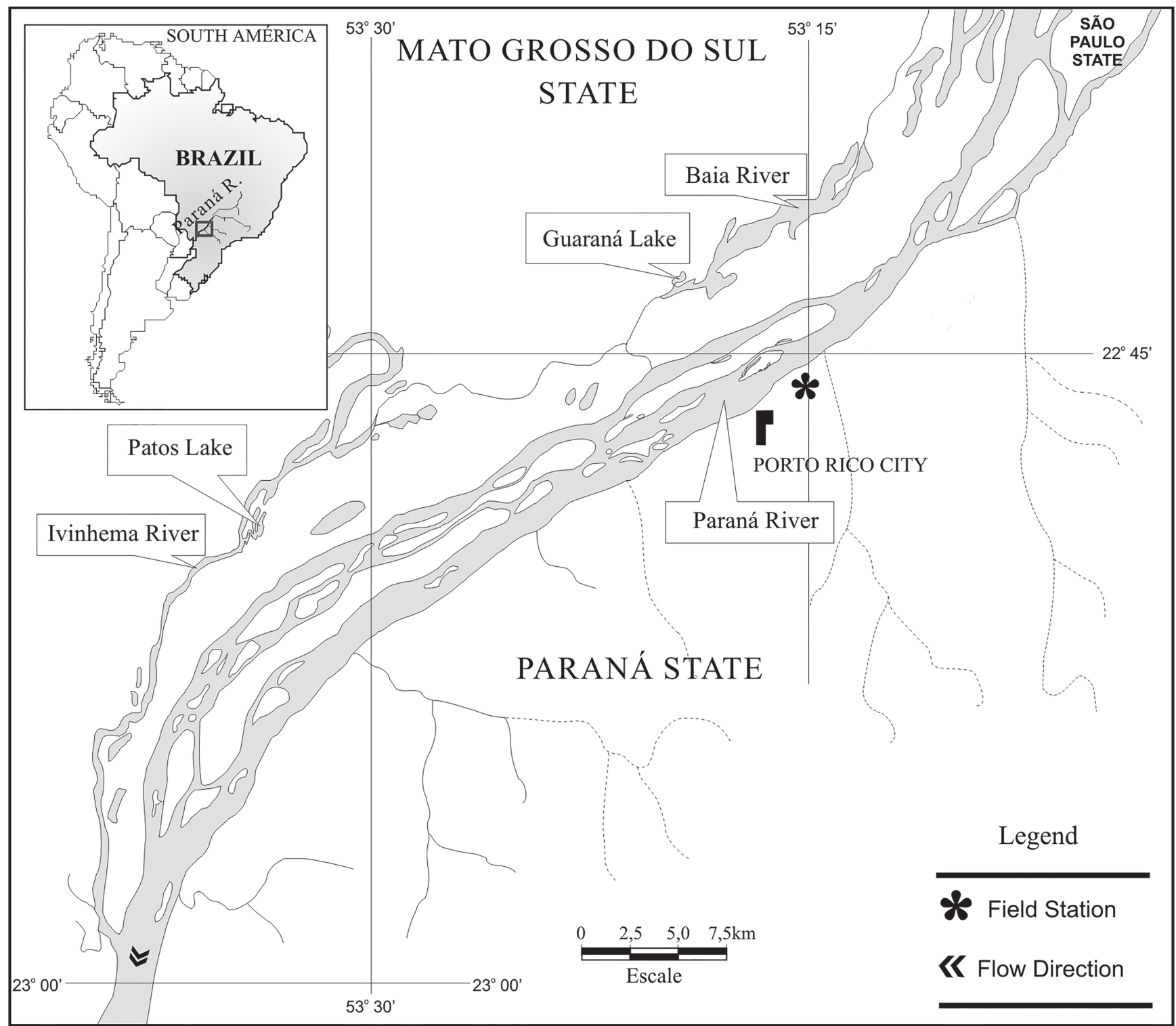

Fig. 1. The upper Paraná River floodplain below Porto Primavera Reservoir and above Itaipu Reservoir, showing the location of sampling stations (in the boxes). 
Sampling sites and statistical analyses. Data on fish assemblages and abiotic variables was supplied by the "Núcleo de Pesquisa em Limnologia, Ictiologia e Aquicultura" - Nupélia, from Universidade Estadual de Maringá. The data are part of a long-term monitoring program of aquatic fauna from the Paraná River floodplain. In this long-term program, quarterly samplings were conducted at five stations distributed throughout the plain (Fig. 1) including the Paraná, Baia and Ivinhema rivers and one connected floodplain lake at Guaraná (connected to Baia River) and another at Patos (connected to Ivinhema River). The four annual samples on February, May, August and November, were replicated during 10 years spread over a 19-year period beginning in 1986 and extending through 2005 (11/1986-08/1988; 05/1992-02/1995; 02/2000$11 / 2002 ; 02 / 2004-11 / 2005)$. This period encompassed the completion of Porto Primavera Reservoir in 1998. Fish sampling was conducted with constant effort of 10 gill nets 20 -m long $(3,4,5,6,7,8,10,12,14$ and $16 \mathrm{~cm}$ stretch measure mesh) in all period. Simultaneously with gill-net collections, we recorded selected abiotic variables including water temperature $\left({ }^{\circ} \mathrm{C}\right)$, Secchi depth $(\mathrm{Secch} i, \mathrm{~m})$, specific conductance $\left(\mu \mathrm{S} / \mathrm{cm}\right.$ at $\left.25^{\circ} \mathrm{C}\right)$, and $\mathrm{pH}$. These variables can be associated both with seasonal variation, as the study area is located in a subtropical region, and with spatial variation on fish abundances because data were collected in three rivers. Water levels were summarized in terms of monthly means (Level; $\mathrm{cm}$ ) and as mean water level above $350 \mathrm{~cm}$ for each October-March period (Flood; cm), which corresponds to the reproductive period of curimba (Gomes, Agostinho, 1997). The 350-cm elevation (Paraná River elevation as recorded in the fluviometric station at Porto São José, which is registered as 64575003 in the ANA - Water National Agency) corresponds to the level at which the connection between river and floodplain is intensified (Thomaz et al., 1997). The variable Flood is referred to herein as the intensity of the flood pulse. Number of days with water levels above $350 \mathrm{~cm}$ (duration of flood) was also calculated, but was not used in the analysis because of the high multicollinearity with Flood (Pearson correlation $=0.93$ ). Multicollinearity is used to infer the impact of correlated predictors on the parameter estimates and can have important, and detrimental effects with predictor variables if they are highly correlated (Quinn, Keough, 2002).

All fish captured were identified to species (Tab. 1) and categorized as piscivorous fish (i.e., piscivores predators of curimba) or illiophagous fish (species that suck the microbial film at the surface of plants and other substrata; food competitors of curimba) based on published categorizations (Hahn et al., 2004; Angelini et al., 2006). The abundance of each fish group was indexed by the capture per unit of effort (CPUE; individuals $/ 100 \mathrm{~m}^{2}$ gill net in $24 \mathrm{~h}$ ) transformed ( $\log _{\text {o }}$ CPUE+1) to meet assumptions of the analysis. CPUE of piscivores was used in the model as a surrogate of predation, whereas CPUE of illiophagous fish (excluding curimba) was used as a surrogate of competition.
Tab. 1. Piscivores (Pred) and illiophagous (Comp) species observed in the upper Paraná River floodplain (Hahn et al., 2004), which were grouped as predators and competitors of Prochilodus lineatus. Voucher specimens deposited in the Ichthyological Collection of Nupélia, NUP.

\begin{tabular}{|c|c|c|c|}
\hline Species & Pred & Comp & Voucher \\
\hline Acestrorhynchus lacustris (Lütken, 1875) & $\mathrm{X}$ & & NUP 7579 \\
\hline Ageneiosus ucayalensis (Castelnau, 1855) & $\mathrm{X}$ & & NUP 4690 \\
\hline Astronotus crassipinnis (Heckel, 1840) & $\mathrm{X}$ & & NUP 1686 \\
\hline Catathyridium jenynsii (Günther, 1862) & $\mathrm{X}$ & & NUP 11912 \\
\hline Cichla kelberi Kullander \& Ferreira, 2006 & $\mathrm{X}$ & & NUP 10817 \\
\hline Cichlassoma paranaense Kullander, 1983 & $\mathrm{X}$ & & NUP 1845 \\
\hline Erythrinus erythrinus (Bloch \& Schneider, 1801) & $\mathrm{X}$ & & NUP 11197 \\
\hline Galeocarax knerii (Steindachner, 1879) & $\mathrm{X}$ & & NUP 257 \\
\hline Hemisorubim platyrhynchos (Valenciennes, 1840) & $\mathrm{X}$ & & NUP 506 \\
\hline Hoplerythrinus unitaeniatus (Agassiz, 1829) & $\mathrm{X}$ & & NUP 11289 \\
\hline Hoplias aff. malabaricus (Bloch, 1794) & $\mathrm{X}$ & & NUP 11457 \\
\hline Megalonema platanum (Günther, 1880) & $\mathrm{X}$ & & NUP 2016 \\
\hline Pinirampus pirinampu (Spix \& Agassiz, 1829) & $\mathrm{X}$ & & NUP 4659 \\
\hline Plagioscion squamosissimus (Heckel, 1840) & $\mathrm{X}$ & & NUP 5993 \\
\hline Pseudoplatystoma corruscans (Spix \& Agassiz, 1829) & $\mathrm{X}$ & & NUP 12165 \\
\hline Rhamdia quelen Quoy \& Gaimard, 1824 & $\mathrm{X}$ & & NUP 410 \\
\hline Rhaphiodon vulpinus Agassiz, 1829 & $\mathrm{X}$ & & NUP 11153 \\
\hline Salminus brasiliensis (Cuvier, 1816) & $\mathrm{X}$ & & NUP 12169 \\
\hline Salminus hilarii Valenciennes, 1849 & $\mathrm{X}$ & & NUP 1892 \\
\hline Serrassalmus maculatus (Kner 1858) & $\mathrm{X}$ & & NUP 5928 \\
\hline Serrassalmus marginatus Valenciennes, 1847 & $\mathrm{X}$ & & NUP 6335 \\
\hline Sorubim lima (Bloch \& Schneider, 1801) & $\mathrm{X}$ & & NUP 10433 \\
\hline Apareiodon affinis (Steindachner, 1879) & & $\mathrm{X}$ & NUP 1540 \\
\hline Parodon nasus Kner, 1859 & & $\mathrm{X}$ & NUP 296 \\
\hline Cyphocharax modestus (Fernández-Yépez, 1948) & & $\mathrm{X}$ & NUP 1569 \\
\hline Cyphocharax nagelii (Steindachner, 1881) & & $\mathrm{X}$ & NUP 1565 \\
\hline Steindachnerina brevipinna (Eigenmann \& Eigenmann, 1889) & & $\mathrm{X}$ & NUP 4589 \\
\hline Steindachnerina insculpta (Fernández-Yépez, 1948) & & $\mathrm{X}$ & NUP 17042 \\
\hline
\end{tabular}

The panel data analysis assessed whether the fish variables (piscivores and competition) and environmental variables ( $\mathrm{pH}$, Secchi, temperature, specific conductance, level and flood) explained spatial (i) and temporal (t) variations in $\ln (\mathrm{CPUE}+1)$ of curimba (surrogate of abundance). Starting with the following model, quadratic or lagged terms of the variables were included to meet error assumptions (at 5\%) and non-significant variables (at 5\%) were excluded successively (Fig. 2):

$\ln (\text { CPUE }+1)_{i, t}=\alpha_{1 i}+\beta_{1}$ Piscivores $_{i, t}+\beta_{2}$ Competition $_{i, t}$ $+\beta_{3} \mathrm{pH}_{i, t}+\beta_{4}$ Secchi $_{i, t}+\beta_{5}$ Temperature $_{i, t}+\beta_{6}$ Specific $^{\prime, t}$ conductance $_{i, t}+\beta_{7}$ Level $_{i, t}+\beta_{8}$ Flood $_{i, t}+\beta_{9}$ PPD $_{i, t}+\varepsilon_{i, t}$

Where $a$ is the intercept, $\beta$ s are the slopes, $e$ is the estimated error with the assumptions of normality, homogeneity of variance and time independence $(e \sim$ $N(0, \sigma)$; $\left.\operatorname{Corr}\left(e_{i, t} e_{i, s}\right)=0, \forall s \neq t\right)$, and PPD is a binomial variable to identify times before and after the filling of Porto 
Primavera Reservoir. The variable $P P D$ represented an indicator variable explored in two alternative forms: (i) one for samples gathered after 1998 and zero otherwise; (ii) one for Baia and Paraná rivers and Guaraná Lake after filling of Porto Primavera Reservoir (sites directly influenced by the Paraná River) and zero otherwise. The other variables included in the model were as defined above.

Special attention was given to diagnostic checks of model assumptions and hypothesis tests derived from it. Possible non-linear relations were evaluated using partial regression plots, and when a significant quadratic relation was detected (with F-test), a quadratic term of the explanatory variable was included in the model. Partial regression plots show relations between response and predictor variables holding other predictor variables constant, and are useful for detecting outliers and non-linear relations (Quinn, Keough, 2002). Spatial effect (intercepts for sites) were evaluated by comparing models of fixed effect (fixed intercept for each site) versus random effect (random intercepts for sites, with Gaussian distribution) following the Hausman's specification test (Hausman, 1978) and the LaGrange's multiplier random effect test (Breusch, Pagan, 1980).
The fixed effects model makes the error term, which is correlated with the variables, to be eliminated through a transformation of fixed effects, called entire transformation. There is also variation among the crosssectional units (between), which is used only in as estimation wherein the intercept is present. In this case, the use of the random effects model is the most suitable (Wooldridge, 2006).

The random effects model considers that the error term is uncorrelated with the variables. Thus, it allows the coefficients to be estimated as a single cross section that is not needed the data structure panel for estimating the model. The fixed effects and random effects models are independent and cannot be applied together in the same regression. The Hausman's specification test, which is based on the difference between the estimators of random and fixed effects, can be applied to decide which model is most appropriate for the regression. The null hypothesis of the Hausman test considers whether the model is random effects. Rejection of this hypothesis implies the adoption of the fixed effects model (Baltagi, 2005). For a review on panel data analysis and random versus fixed effects models we recommend Greene (2003).

\section{Panel data analysis}

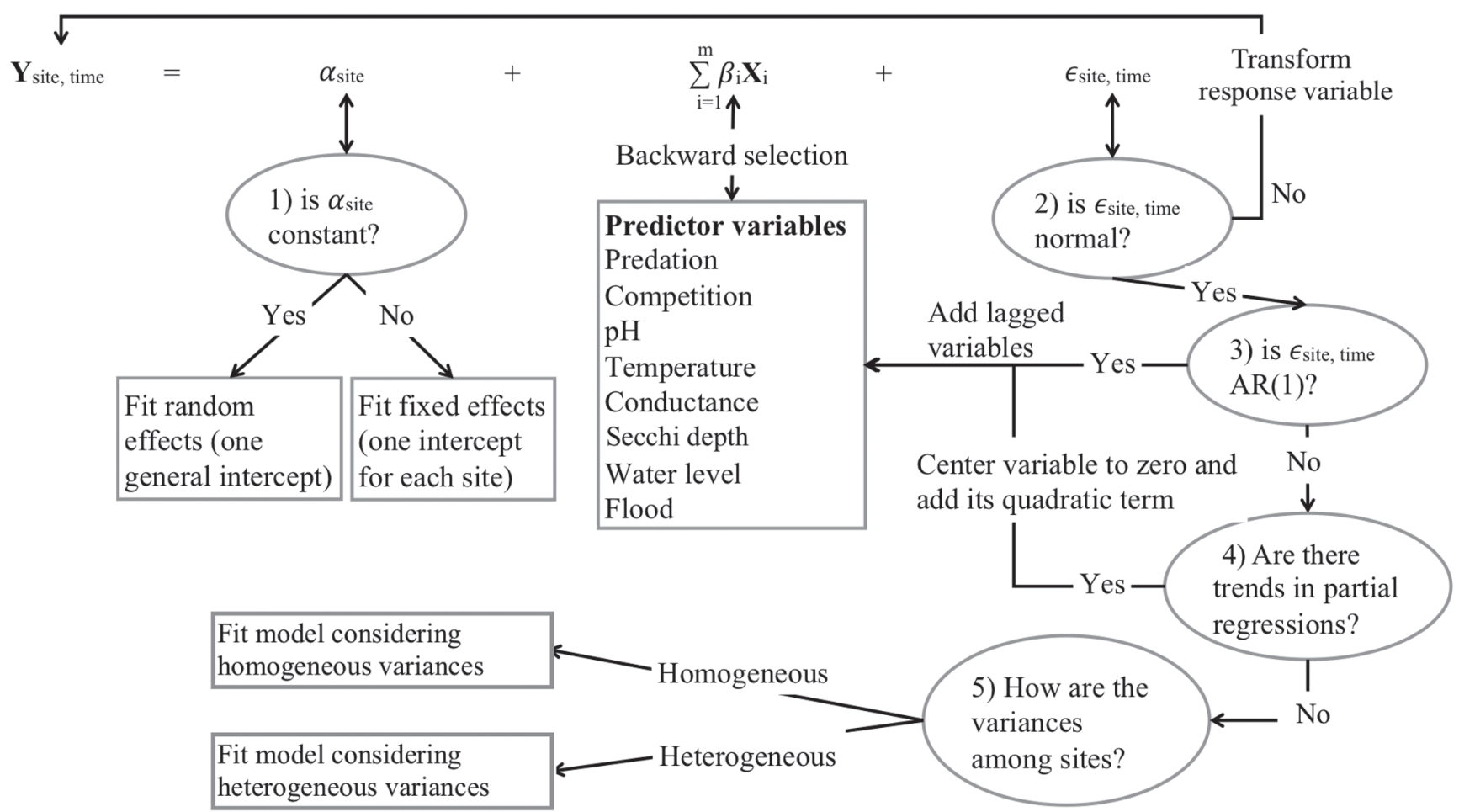

Fig. 2. Flowchart used for panel data analysis. Predictor variables with variance inflation factor bigger than 10 were removed to avoid multicollinearity. Question one was evaluated with Hausman's specification test (Hausman, 1978) and the LaGrange's multiplier random effect test (Breusch, Pagan, 1980); question two with Shapiro-Wilk test; question three for time auto-correlation (AR) in residuals with the test of first-order serial correlation (Drukker, 2003); question four with $\mathrm{F}$ test; and question five with the modified Wald's test for homogeneity of variance (Greene, 2003). 
Multicollinearity between predictor variables was checked with the variance inflation factor (VIF). Homogeneity of variances among sites was checked with the modified Wald's test (Greene, 2003), and the possibility of time auto-correlation (AR) in residuals with the test of first-order serial correlation (Drukker, 2003). Positive first-order correlations are common in biology data because observations collected in adjacent times are more alike than those randomly collected. This problem can result in underestimates of the residuals variance and increase the Type I error associated with hypotheses test on parameter estimates (Quinn, Keough, 2002). In case of significant AR process, we explored lagged (from one to three years) versions of predictor's variables to remove auto-correlation from residuals. A plot of standardized normal probability with Shapiro-Wilk test evaluated normality in the residuals. All significance tests were carried out at the 5\% significance level in Stata software $8.0^{\circledR}$.

\section{Results}

We recorded a decrease in the abundance of curimba over the 19-year study period across all sampling sites (Fig. 3a). In contrast, an increase in the abundance of piscivores was observed, except at the Patos Lake and Paraná River sites, where abundances of piscivores showed no detectable changes (Fig. 3b). Abundance of competitors increased at the Paraná River and Ivinhema River sites, but decreased at Patos Lake. There were also slight decreases in competitor abundances at Guaraná Lake and at the Baia River site (Fig. 3c).
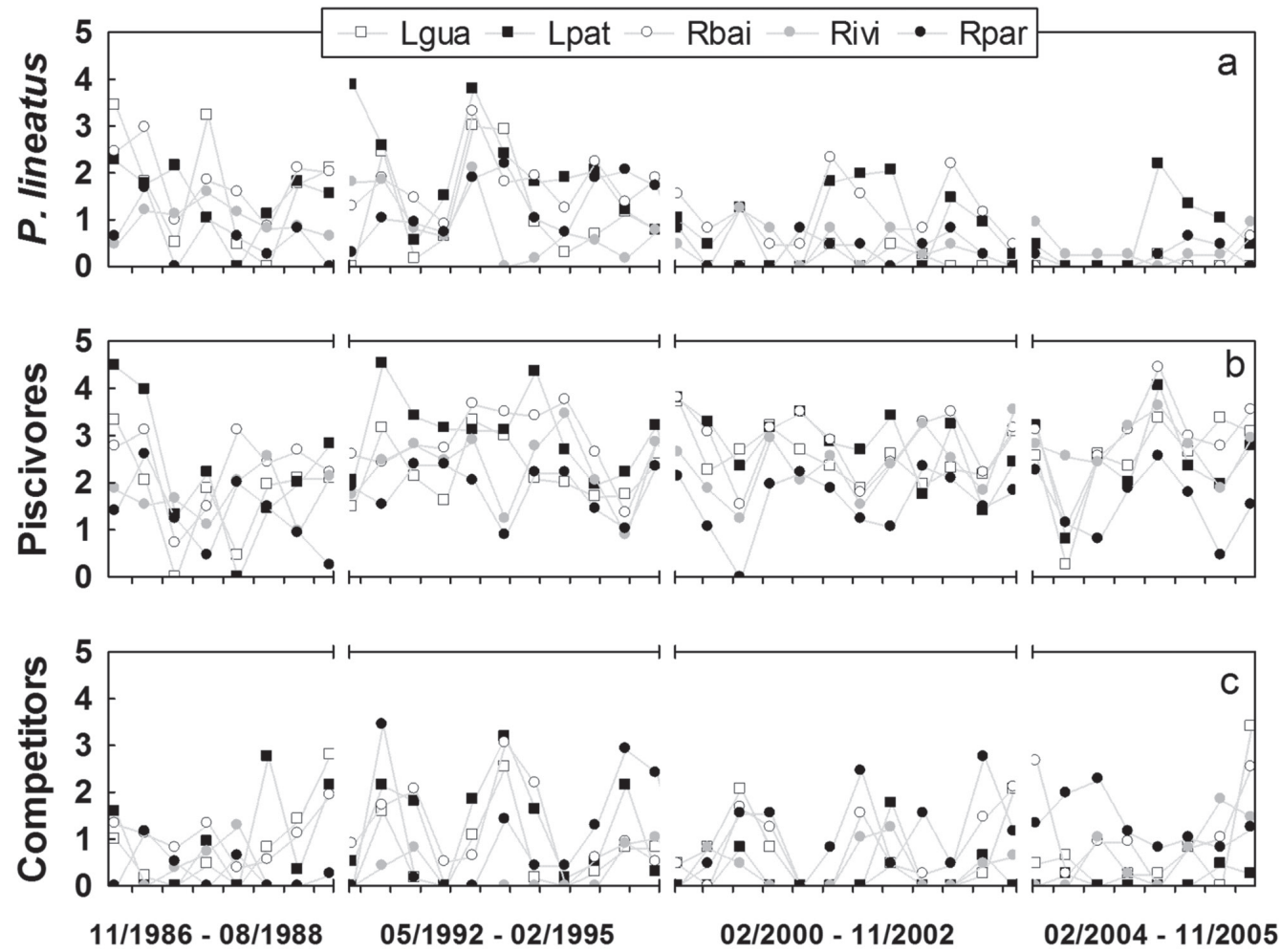

Fig. 3. Interrupted time series for numerical abundances $(\ln (\mathrm{CPUE}+1)$ transformed $)$ of a. Prochilodus lineatus; b. piscivores; and c. competitors; in Guaraná (Lgua) and Patos (Lpat) lakes and Baia (Rbai), Ivinhema (Rivi) and Paraná (Rpar) rivers, in the period from $11 / 1986$ to $11 / 2005$.

Among the abiotic variables, $\mathrm{pH}$ values were near neutrality, ranging between 5.5 and 8.0. On average, the Paraná River site exhibited the highest $\mathrm{pH}$ values, whereas Guaraná Lake the lowest. Except for Guaraná Lake, we noted a slight tendency of decrease in $\mathrm{pH}$ (Fig. 4a). Secchi depth varied distinctly considering each site. For Patos Lake and Guaraná Lake as well as the Baia River site, Secchi depth was higher in the second period (05/1992 02/1995). Secchi depth varied less in the Ivinhema River site, whereas in the Paraná River site there was a sharp tendency for increased water clarity over the study years (Fig. 4b).

Cyclical variations in water temperature were observed (minimum of 16 and maximum of $32{ }^{\circ} \mathrm{C}$ ), with a slight increasing trend over the years. Site differences in temperature were small when compared to seasonal differences (Fig. 4c). Specific conductance was higher in the Paraná River and Ivinhema River sites. The Baia River site, and Patos and Guaraná lakes showed lower values; the lakes, showed seasonal cycles, with high values in hot months (Fig. 4d). 

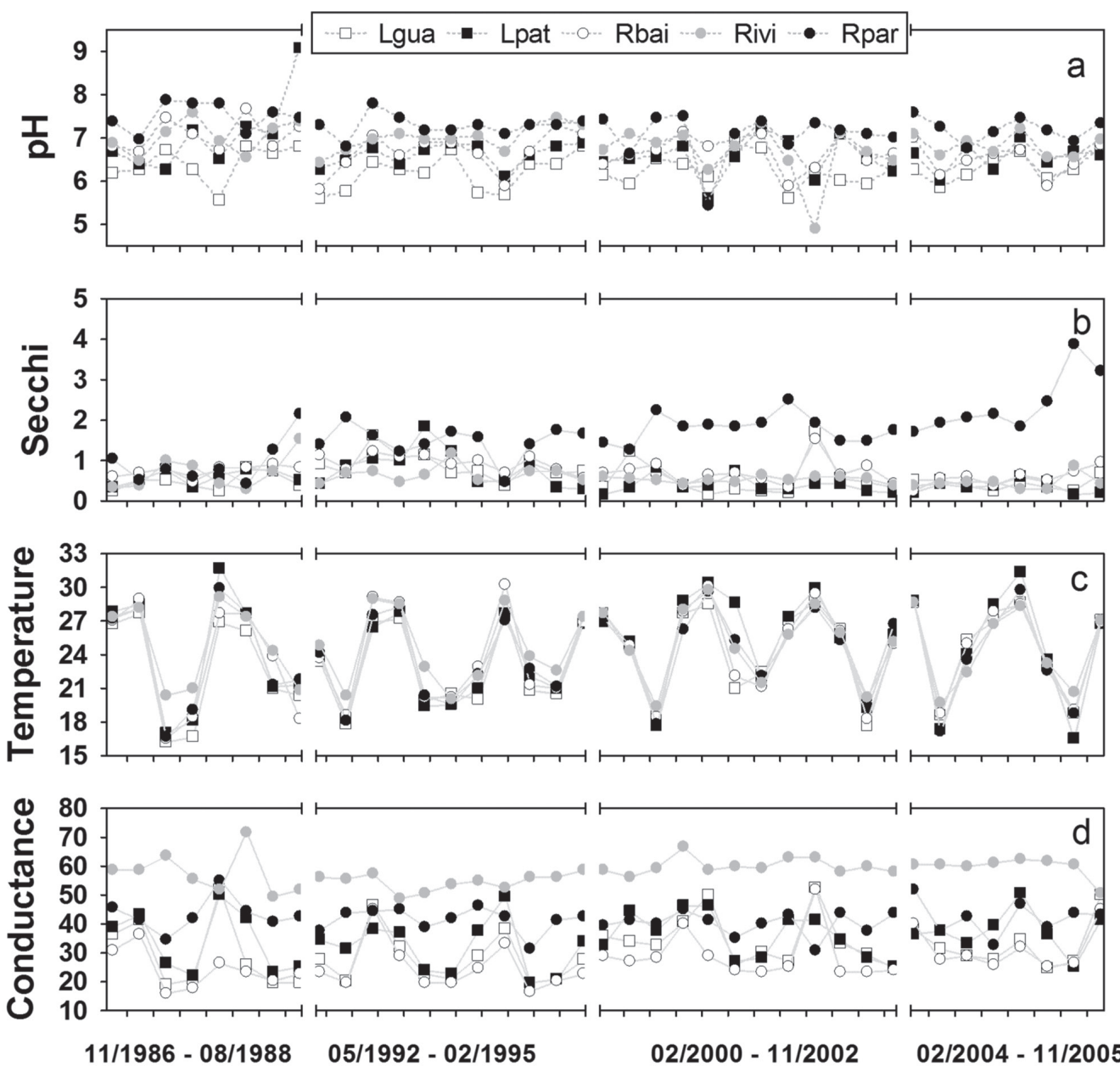

Fig. 4. Interrupted time series for a. $\mathrm{pH}$; b. Secchi depth $(\mathrm{cm})$; c. Water temperature $\left({ }^{\circ} \mathrm{C}\right)$; and d. Specific conductance $(\mu \mathrm{S} /$ $\mathrm{cm}$ ); in Guaraná (Lgua) and Patos (Lpat) lakes and Baia (Rbai), Ivinhema (Rivi) and Paraná (Rpar) rivers, in the period from $11 / 1986$ to $11 / 2005$.

Water level in the Paraná River, averaged higher values in the 1990s (Fig. 5). No major floods occurred in the region during the spawning seasons (October-March) of 1985-1986 and 1986-1987, and after the closure of Porto Primavera Dam in 1998. However, intense floods occurred in the spawning seasons (October-March) of 1984-1985 (prior to our samplings), in all spawning seasons of 1990-1995, and of 2004-2005.

The process of model selection identified competition, specific conductance, flood level of the previous year in the Paraná River, and closure of Porto Primavera Dam (indicator variable) as significantly correlated to the abundances of curimba (Fig. 6). Abundances of competitors were directly related to abundances of curimba (Fig. 6a), specific conductance was inversely related (Fig. 6b), whereas floods were also related to curimba abundance in a quadratic form (floods with intermediate mean water level tended to produce the lowest abundances; Fig. 6c). Spatial differences were detected by the Hausman's test $\left(\chi_{(5)}^{2}=11.75 ; p=0.02\right)$, and by the LaGrange Multiplier random effect test $\left(\chi_{(1)}^{2}=\right.$
$7.43 ; p=0.005)$, indicating that a considerable part of the spatial variability cannot be attributed to the measured variables; thus, it was necessary to fit the fixed effect model to avoid bias in the estimated parameters (see Greene, 2003).

No multicollinearity was detected among the selected explanatory variables (VIF $<1.1$, for all continuous variables), but no homogeneous variance was observed among sites $\left(\chi_{(5)}^{2}=28.52 ; p<0.0001\right)$. Time dependences in residual series (AR (1)) were not significant $\left(\mathrm{F}_{(1}\right.$, $\left.{ }_{4)}=5.8 ; p=0.07\right)$ after the inclusion of one-year lag version of the flood predictor variable. However, for the period after the closure of Porto Primavera Dam, the Paraná River and Baia River sites as well as Patos Lake showed significantly lower abundances of curimba when compared to the pre-impoundment period (Fig. 6d). Thus, the fitted model was a fixed effect model with heteroscedastic variances, without autocorrelation, and with normal residuals distributions. This model explained about $35 \%$ of the variability within sites (time $(t)$ variation; $\mathrm{R}^{2}$ within panel), $52 \%$ between sites (spatial $(i)$ 
variation; $\mathrm{R}^{2}$ ), and $37 \%$ of the total variability $\left(\mathrm{R}^{2}\right.$ overall $)$. The mathematical representation of the model is: $\ln (\mathrm{CPUE}+1)_{i, t}=\left(22+0.1957\right.$ Competitors $_{i, t}-0.0211$ Specific conductance $_{i, t}-0.099$ Flood $_{i, t-1}+1.2 \times 10^{-4}$ Flood $i_{i, t-1}^{2}-0.606 P P D_{i, t}$ where variable names are as defined earlier (competitors ( $\mathrm{SE}=0.0605 ; \quad \mathrm{Z}=3.24 ; \quad \mathrm{p}=0.001)$, specific conductance $(\mathrm{SE}=0.0067 ; \mathrm{Z}=-6.13 ; \mathrm{p}<0.001)$, Flood $(\mathrm{SE}=0.0303 ; \mathrm{Z}=-$ $3.27 ; \mathrm{p}=0.001)$, Flood2 $(\mathrm{SE}=4 \times 10-5 ; \mathrm{Z}=3.32 ; \mathrm{p}=0.001)$, PPD $(\mathrm{SE}=0.1489 ; \mathrm{Z}=-4.07 ; \mathrm{p}<0.001))$.

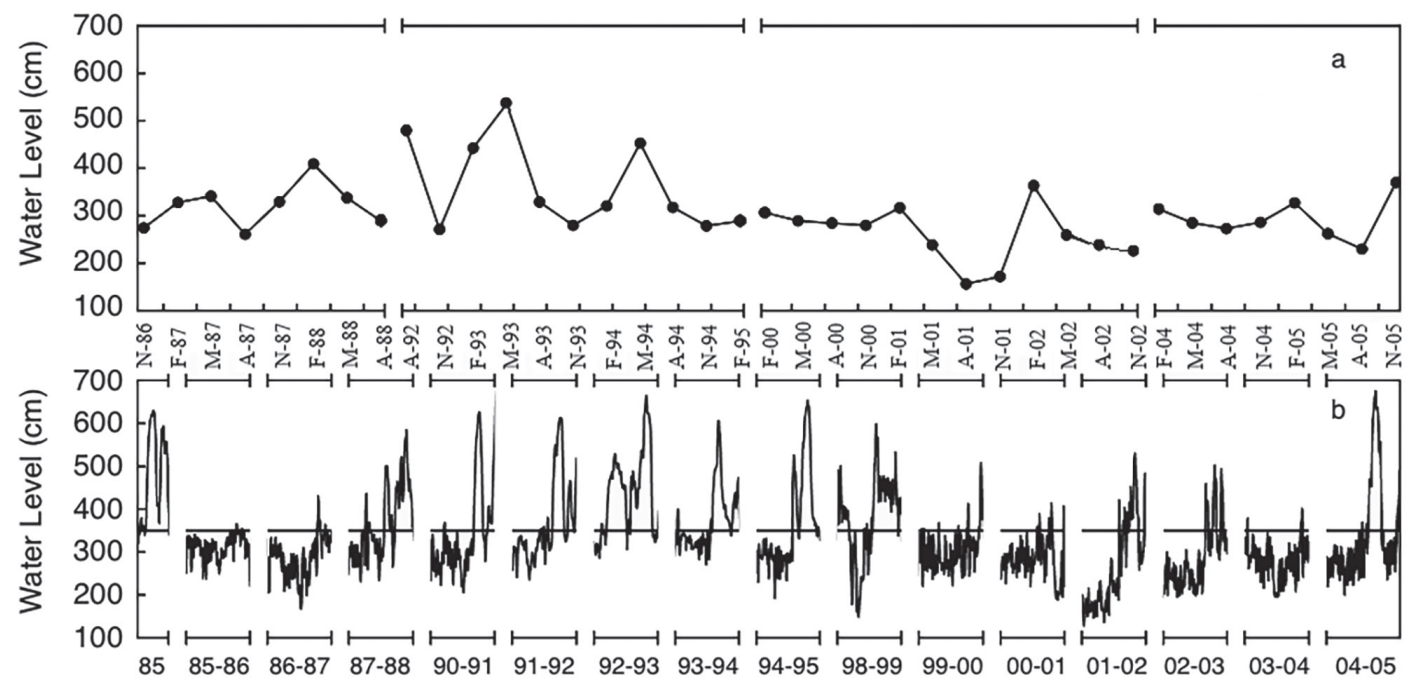

Fig. 5. Water level $(\mathrm{cm})$ variations in the upper Paraná River: a. monthly averages during the study period; b. daily averages in the period from October to March (spawning season of Prochilodus lineatus). Data gathered from the fluviometric station of Porto São José. The $350 \mathrm{~cm}$ value is the elevation at which the connection between the Paraná River and the floodplain is intensified (Thomaz et al., 1997).
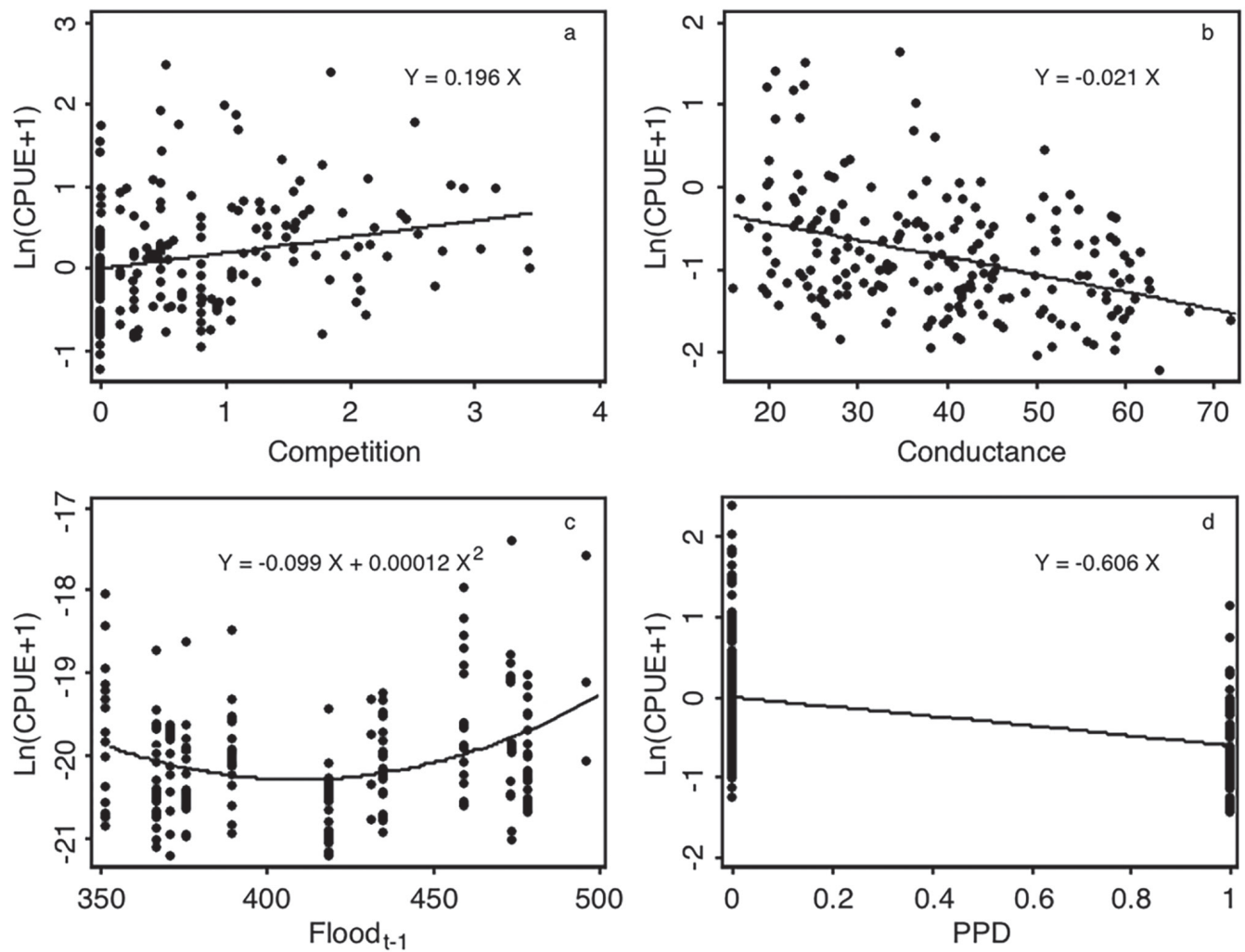

Fig. 6. Partial regressions for Prochilodus lineatus abundances $(\ln (\mathrm{CPUE}+1))$ as a function of the abundance of a. competitors $(\ln (\mathrm{CPUE}+1) ; \mathbf{b}$. Specific conductance $(\mu \mathrm{S} / \mathrm{cm}) ; \mathbf{c}$. Flood of the previous year in the Paraná River $(\mathrm{cm})$; and d. Porto Primavera Dam (1 for Baia and Paraná rivers and Guaraná Lake after the closure of Porto Primavera Dam (in 1998) and 0 otherwise). 


\section{Discussion}

The curimba is a large-sized species that exhibits high biomass in several South American rivers, and accordingly has high economic importance for freshwater fishers and for people that live near rivers (Taylor et al., 2006). This species uses the upper Paraná River floodplain as a nursery area, for one or two years, during a period in which they attain large sizes that allow them to minimize predation when they return to the main channel of rivers and are recruited to fisheries (Agostinho et al., 1993; Gomes, Agostinho, 1997). Information on commercial fishery landings for the Itaipu Reservoir, located immediately below the upper Paraná River floodplain, indicate decreased catches through time (Okada et al., 2005). In addition, Gubiani et al. (2010) showed a sharp decrease in the abundance of curimba in the Piquiri River, an important tributary on the eastern margin of the Paraná River, showing possible regional effects on the population of the species. Causes for the decline are still obscure. However, a great deal of the decline has been attributed to modification of the hydrological regime by the cascade of dams located upstream from the floodplain (Gomes, Agostinho, 1997; Agostinho et al., 2004a).

The curimba is an illiophagous species that feeds on fine debris and microbial film on plant surfaces (Fugi et al., 1996). Its competitors in the region are members of the families Curimatidae and Parodontidae (Angelini et al., 2006) that occur in high abundances in floodplain lakes. The abundances of curimba and its competitors showed different trends in the two rivers; they increased in the Paraná and decreased in the Ivinhema. Thus, low and high abundance of both (curimba and its competitor) coincided, which resulted in the positive slope for the variable competitor. This result contradicted our expectation that the presence of competitors would lead to a negative slope, suggesting that the same factors that affected the populations of curimba also influenced populations of Curimatidae and Paradontidae. In the region, and also identified by the model, the alteration in the hydrological regime prompted by the closure of Porto Primavera Dam, exacerbated by the cascade of dams upstream, promotes the sink of suspended material, including nutrients (Agostinho et al., 2001). This process impoverishes water of the Paraná main channel, as has also been reported in other regions (Ward, Stanford, 1995; Ney, 1996). In fact, Agostinho, Zalewski (1995) reported that the upper Paraná River, below the cascade of dams, during floods, removes nutrients from the plain due to low concentrations in its waters, affecting primary production in floodplain environs. The impacts of the cascade of dams are not observed in the Ivinhema basin (Ivinhema River and Patos Lake), except during large floods. In addition, during low water, especially in floodplain lakes, the food sources used by these species are abundant, precluding competition among illiophagous species (Bowen et al., 1984).

Negative impacts of Porto Primavera Dam were also observed for ichthyoplankton. After the formation of
Porto Primavera Reservoir, occurrence of larvae of many migratory species has been restricted to rivers without dams, such as the Ivinhema (Sanches et al., 2006). Reservoirs retain water, changing the natural hydrograph, redistributing water along time. This change reduces maximum levels and increases minimum levels. However, hydroelectric dams such as the one positioned above the study floodplain, promote increased daily variations (Agostinho et al. 2007). According to Agostinho et al. (2008) and Louca et al. (2009), the biological diversity in floodplains below dams is greatly modified because of alterations in the hydrological regime, retention of nutrients and sediments, and accelerated erosion in the river bed.

The importance of the hydrological regime in the Paraná River was evidenced by the significant indicator variable that represented the closure of Porto Primavera Dam. The abundances of curimba before the damming were significantly higher than after the damming. However, most of the individuals caught before and after the closure of the dam were 1-2 years old (normal distribution of standard length with $19.6 \mathrm{~cm}$ mean and $4.8 \mathrm{~cm}$ standard deviation), reflecting the importance of the floods on the reproduction and recruitment of curimba. An ad-hoc hypothesis to explain the relationship with water levels of the previous year indicate that the observed quadratic effect was due to the elevated abundance of curimba in 1987 (16\% of the individuals were older than two years; Gomes, Agostinho, 1997), but there was no flood in 1985-1986 (average water level of $352 \mathrm{~cm}$ ). The high abundance of curimba in 1987 may be explained by the intense flood that occurred in the spawning season of 1984-1985, with average water level of $496 \mathrm{~cm}$, which resulted in high abundances of curimba in 1986 that echoed into 1987. Thus, the quadratic effect with the flood should be interpreted as a legacy effect of previous intense floods (1984-1985). This effect accounts for the atypical behavior observed in 1987, and as identified by for the model, the only positive effect on $P$. lineatus abundance was produced by flood intensities above $450 \mathrm{~cm}$ at fluviometric station of Porto São José.

Our observations corroborate those of Baumgartner et al. (1997), who reported positive correlations between the abundances of eggs and larvae with water level. In addition, Gubiani et al. (2007) called attention to the need for floods to the persistence of curimba, as they noted that during dry periods, the fraction of patches (sites) unoccupied by curimba increased drastically. However, the overflow of waters from the Paraná River onto the floodplain, that occurs when water level reaches $350 \mathrm{~cm}$, is not enough for the spawning success and recruitment of the species. In our study, water levels above $450 \mathrm{~cm}$ significantly affected the abundance of curimba, similarly to what has been reported for piscivorous fishes (Piana et al. unpublished). Similarly, Comunello (2001) observed that meaningful floods in the adjacent Ivinhema River floodplain occurred only when water levels of the Paraná River exceeded $450 \mathrm{~cm}$. High water levels, duration, and timing of floods have already 
been cited as important attributes for the maintenance of fluvial species in the Neotropical realm (Agostinho et al., 2004a), as well as other regions (Miranda, 2001; Bunn, Arthington, 2002). We were unable to analyze the relative importance of flood duration as duration and intensity were highly correlated $(r=0.93)$. However, duration of the flood was indexed by the water level during the spawning season (variable flood).

Specific conductance was inversely related with curimba abundances. An increasing trend in water specific conductance has been linked to construction of upstream dams. Vazzoler (1996) cites the increase in conductance as an environmental cue that triggers spawning. However, conductance in our study did not seem related to reproduction and the values registered were not harmful to freshwater fish. The best explanation to the positive effect of conductance appears to be a characteristic of the biology of migratory fish, including curimba. These fish, in early life stages, inhabit standing water bodies of the upper Paraná River floodplain, which undergo severe changes in water quality, such as oxygen, temperature and conductance during the dry season (Agostinho et al., 2004a; Thomaz et al., 2007). Therefore, specific conductance may be interpreted as a space segregation variable, which also indicates food availability and shelter, and is related to the life strategy of the selected model species curimba. Reash, Pigg (1990) reported that in an $811 \mathrm{~km}$ stretch of a temperate river, physical and chemical factors influencing fish assemblages varied longitudinally. In their study, the effect of specific conductance alternated between positive and negative according to the position in the stretch. Alterations in physical and chemical conditions affect species in distinct ways, favoring some in detriment of others (Jackson et al., 2001).

Despite the low explanatory value of the model, we were able to identify prior-season water level as the variable regulating abundances of curimba in the upper Paraná River floodplain. Specific conductance influenced the spatial distribution of curimba within the floodplain. In addition, the closure of Porto Primavera Dam also acted on the spatial distribution of the abundance of curimba, once the dam fragmented the spawning ground of the species or led to changed specific conductance in the Paraná River. This finding is supported by the decrease in larvae density in the environments of the Paraná and Baia rivers, as stated by Sanches et al. (2006).

The importance of ecological studies based on long-time series of cross-sections has been recognized (Thomas, 1996). Such series generally contain recurrent variations of diverse factors that operate at distinct scales. Seasonal variations, long-term trends, and spatial segregations are components of populations that, after identified and explained, can be used to develop strategies to maintain biological diversity and abundance. Panel data analysis was of value for such data because it considers the components of time series (seasonal variations and trends) and transversal sections (spatial segregation) simultaneously. Panel data analysis enabled us to develop insight about curimba population regulation in the Upper Paraná River floodplain. Firstly, biological interactions were not fundamental for population regulation, given the lack of relation with the abundance of piscivores and the positive relation with competitors. Secondly, spatial variability in abundance was attributed to environmental conditions, specifically to specific conductance of the water, but it may be interpreted as a result of the life strategy of the species. However, a large fraction of the variability was not explained by the model, suggesting that the predictability of the panel analysis may be improved. To improve it, other variables have to be considered. For the case of the illiophagous curimba, the amount of macrophytes and the type and composition of the substrates may need to be considered in future studies. Lastly, time variations were partially determined by the intensity (average value of the water levels above $350 \mathrm{~cm}$ in the fluviometric station of Porto São José, Paraná River) of the flood during the spawning season and by the closure of Porto Primavera Dam in 1998. The flood was essential for fostering high abundances of curimba, whereas the construction of Porto Primavera Reservoir negatively affected curimba abundances in the Paraná River and Baia River sites and Guaraná Lake. Such influence was not observed in the Ivinhema River site and Patos Lake; these sites were less influenced by the water levels of the Paraná River.

In conclusion, the population regulation of curimba in the upper Paraná River floodplain was more influenced by the water levels during the spawning season of the previous year. Thus, annual floods that surpass the 450-cm level at the fluviometric station of Porto São José, lasting about three consecutive months, are necessary to maintain high abundances of the species in the region. Luz-Agostinho et al. (2009) showed that floods occurring every two years were better to the body condition of migratory fish than floods occurring every year. Intervallic floods may supply proper conditions for the species to migrate and spawn, and nursery areas for the offspring. The same may be true for other migratory species. Therefore, periodic floods with sufficient intensity and duration may contribute to maintain biological diversity and high abundances of fish, and should be key elements of management plans for the operation of upstream dams.

\section{Acknowledgments}

Sincere thanks are directed to Nupélia for supplying the database used to accomplish this study. We also thank researchers of Nupélia for the valuable information supplied and Coordenação de Aperfeiçoamento de Pessoal de Ensino Superior for the financial support for Pitágoras Augusto Piana. Angelo Antonio Agostinho and Joilson Dias are granted by Bolsa Produtividade em Pesquisa (PQ) of Conselho Nacional de Desenvolvimento Científico e Tecnológico. 


\section{References}

Agostinho AA, Gomes LC, Pelicice FM. Ecologia e manejo de recursos pesqueiros em reservatórios do Brasil. Maringá: Eduem; 2007.

Agostinho AA, Gomes LC, Veríssimo S, Okada EK. Flood regime, dam regulation and fish in the Upper Paraná River: effects on assemblage attributes, reproduction and recruitment. Rev Fish Biol Fish. 2004a; 14:11-19.

Agostinho AA, Gomes LC, Zalewski M. The importance of floodplains for the dynamics of fish communities of the upper River Paraná. Ecohydrol Hydrobiol. 2001; 1(1):209-17.

Agostinho AA, Pelicice FM, Gomes LC. Dams and the fish fauna of the Neotropical region: impacts and management related to diversity and fisheries. Braz J Biol. 2008; 68(Suppl.4):1119-32.

Agostinho AA, Thomaz SM, Gomes LC. Threats for biodiversity in the floodplain of the upper Paraná River: effects of hydrological regulation by dams. Ecohydrol Hydrobiol. 2004b; 4(3):255-68.

Agostinho AA, Vazzoler AEAM, Gomes LC, Okada EK. Estratificación espacial y comportamiento de Prochilodus scrofa en distintas fases del ciclo de vida, en la planície de inundación del alto rio Paraná y embalse de Itaipu, Paraná, Brazil. Rev Hydrobiol Trop. 1993; 26(1):79-90.

Agostinho AA, Zalewski M. The dependence of fish community structure and dynamics on floodplain and riparian ecotone zone in Paraná River, Brazil. Hydrobiologia. 1995; 303:141-148.

Agostinho CS, Júlio Júnior HF. Observation of an invasion of the piranha Serrasalmus marginatus Valenciennes, 1847 (Osteichthyes, Serrasalminae) into the Upper Paraná River, Brazil. Acta Sci Biol Sci. 2002; 24:391-95.

Alexandre PC, Luiz EA, Piana PA, Gomes LC, Agostinho AA. Relação estoque-recrutamento para as piranhas Serrasalmus marginatus (Valenciennes, 1847) e S. maculatus (Kner, 1860) no rio Baía, alto rio Paraná. Acta Sci Biol Sci. 2004; 26:303-07.

Angelini R, Agostinho AA, Gomes LC. Modeling energy flow in a large Neotropical reservoir: a tool to evaluate fishing and stability. Neotrop Ichthyol. 2006; 4(2):253-60.

Baltagi BH. Econometric analysis of panel data. 3rd ed. England: John Wiley \& Sons Ltd; 2005.

Baumgartner G, Nakatani K, Cavicchioli M, Baumgartner MST. Some aspects of the ecology of fish larvae in the floodplain of the high Paraná River, Brazil. Rev Bras Zool. 1997; 14(3):551-63.

Bowen SH, Bonetto AA, Ahlgren MO. Microorganisms and detritus in the diet of a typical neotropical riverine detritivore, Prochilodus platensis (Pisces, Prochilodontidae). Limnol Oceanogr. 1984; 29(5):1120-22.

Breusch TS, Pagan AR. The Lagrange multiplier test and its applications to model specification in econometrics. R E Stud. 1980; 47(1):239-53.

Bunn SE, Arthington AA. Basic principles and ecological consequences of altered flow regimes for aquatic biodiversity. Environ Manage. 2002; 30(4):492-507.

Comunello E. Dinâmica de inundação de áreas sazonalmente alagáveis na planície aluvial do alto rio Paraná. [MSc Dissertation]. Maringá, PR: Universidade Estadual de Maringá; 2001.
Drukker DM. Testing for serial correlation in linear panel-data models. The Stata Journal. 2003; 3(2):168-77.

Fugi R, Hahn NS, Agostinho AA. Feeding styles of five species of bottom-feeding fishes of the high Paraná River. Environ Biol Fishes. 1996; 46(3):297-307.

Gomes LC, Agostinho AA. Influence of the flooding regime on the nutritional state and juvenile recruitment of the curimba, Prochilodus scrofa, Steindachner, in upper Paraná River, Brazil. Fish Manag Ecol. 1997; 4:263-74.

Greene WH. Econometric analysis. 5th ed. New Jersey: Prentice Hall; 2003.

Gubiani EA, Gomes LC, Agostinho AA, Baumgartner G. Variations in fish assemblages in a tributary of the upper Paraná River, Brazil: A comparison between pre and post-closure phases of dams. River Res Appl. 2010; 26(7):848-65.

Gubiani EA, Gomes LC, Agostinho AA, Okada EK. Persistence of fish populations in the upper Paraná River: effects of water regulation by dams. Ecol Freshwat Fish. 2007; 16:191-97.

Hahn NS, Fugi R, Andrian IF. 2004. Trophic ecology of the fish assemblages. In: Thomaz SM, Agostinho AA, Hahn NS, editors. The upper Paraná River and its floodplain. Leiden: Backhuys Publishers; 2004. p.247-70.

Hausman JA. Specification tests in econometrics. Econometrica. 1978; 46:1251-71.

Hixon MA, Palaca SW, Sandin SA. Population regulation: historical context and contemporary challenges of open versus closed systems. Ecology. 2002; 83(6):1490-508.

Jackson DA, Peres-Neto PR, Olden JD. What controls who is where in freshwater fish communities - the roles of biotic, abiotic, and spatial factors. Can J Fish Aquat Sci. 2001; 58:157-70.

Junk WJ, Bayley PB, Sparks RE. The flood pulse concept in riverfloodplain systems. In: Dodge DP, editor. Proceedings of the International Large River Symposium. Can Spec Publ Fish Aquat Sci: Canadian Government Publishing Centre/Canada Communication Group; 1989; 110-127.

Legendre P, Legendre L. Numerical ecology: developments in environmental modelling. 2th ed. Amsterdam: Elsevier; 1998.

Louca V, Lindsay SW, Majambere S, Lucas MC. Fish communities characteristics of the lower Gambia River floodplains: a study in the last major undisturbed West African river. Freshwater Biol. 2009; 54(2):254-71.

Luz-Agostinho KDG, Agostinho AA, Gomes LC, Júlio Júnior HF, Fugi R. Effects of flooding regime on the feeding activity and body condition of piscivorous fish in the Upper Paraná River floodplain. Braz J Biol. 2009; 69(Suppl.2):481-90.

Miranda LE. A review of guidance and criteria for managing reservoirs and associated riverine environments to benefit fish and fisheries. In: Marmulla G, editor. Dams, fish and fisheries. Opportunities, challenges and conflict resolution. Rome: FAO Fisheries Technical Paper; 2001. p.91-138.

Neiff JJ. Ideas para la interpretacion ecológica del Paraná. Interciencia. 1990; 15:424-41.

Ney JJ. Oligotrophication and its discontents: effects of reduced nutrient loading on reservoir fisheries. In: Miranda LE, Devries DR, editors. Multidimensional approaches to reservoir fisheries management. Bethesda: American Fisheries Society; 1996. p.285-295. 
Okada EK, Agostinho AA, Gomes LC. Spatial and temporal gradients in artisanal fisheries of a large Neotropical reservoir, the Itaipu Reservoir, Brazil. Can J Fish Aquat Sci. 2005; 62(3):714-24

Okada EK, Agostinho AA, Petrere Junior M, Penczak T. Factors affecting fish diversity and abundance in drying pools and lagoons in the upper Paraná River basin, Brazil. Ecohydrol Hydrobiol. 2003; 3(1):97-110.

Petry AC, Gomes LC, Piana PA, Agostinho AA. The role of the predatory trahira (Pisces: Erythrinidae) in structuring fish assemblages in lakes of a Neotropical floodplain. Hydrobiologia. 2010; 651:115-26.

Piana PA, Gomes LC, Agostinho AA. Comparison of predator-prey interaction models for fish assemblages from the Neotropical region. Ecol Model. 2006a; 192(1-2):259-70.

Piana PA, Gomes LC, Cortez EM. Factors influencing Serrapinnus notomelas (Characiformes: Characidae) populations in upper Paraná River floodplain lagons. Neotrop Ichthyol. 2006b; 4(1):81-86.

Quinn GP, Keough MJ. Experimental design and data analysis for biologists. Cambridge: Cambridge University Press; 2002.

Reash RJ, Pigg J. Physicochemical factors affecting the abundance and species richness of fishes in the Cimarron River. POAS. 1990; 70:23-28.

Sanches PV, Nakatani K, Bialetzki A, Baumgartner G, Gomes LC, Luiz EA. Flow regulation by dams affecting ichthyoplankton: The case of the Porto Primavera dam, Paraná River, Brazil. River Res Appl. 2006; 22(5):555-65.

Suzuki HI, Vazzoler AEAM, Marques EE, Lizama MAP, Inada P. Reproductive ecology of the fish assemblages. In: Thomaz SM, Agostinho AA, Hahn NS, editors. The upper Paraná River and its floodplain. Leiden: Backhuys Publishers; 2004. p.271-91.
Taylor BW, Flecker AS, Hall Jr. RO. Loss of a harvested fish species disrupts carbon flow in a diverse tropical river. Science. 2006; 313(5788):833-36.

Thomas L. Monitoring long-term population change: why are there so many analysis methods? Ecology. 1996; 77(1):49-58.

Thomaz SM, Bini LM, Bozelli RL. Floods increase similarity among aquatic habitats in river-floodplain systems. Hydrobiologia. 2007; 579:1-13.

Thomaz SM, Roberto MC, Bini LM. Caracterização limnológica dos ambientes aquáticos e influência dos níveis fluviométricos. In: Vazzoler AEAM, Agostinho AA, Hahn NS, editors. A planície de inundação do alto rio Paraná: aspectos físicos, biológicos e sócioeconômic. Maringá: Eduem; 1997. p.73-102.

Turchin P. Does population ecology have general laws? Oikos. 2001; 94(1):17-26.

Vazzoler AEAM. Biologia da reprodução de peixes Teleósteos: teoria e prática. Maringá: Eduem; 1996.

Ward JV, Stanford JA. The serial discontinuity concept: extending the model to floodplain rivers. Regul River. 1995; 10:159-68.

Wooldridge JM. Introdução à econometria: uma abordagem moderna. São Paulo: Thomson; 2006.
Submitted May 3, 2016

Accepted August 21, 2017 by Paulo Pompeu 